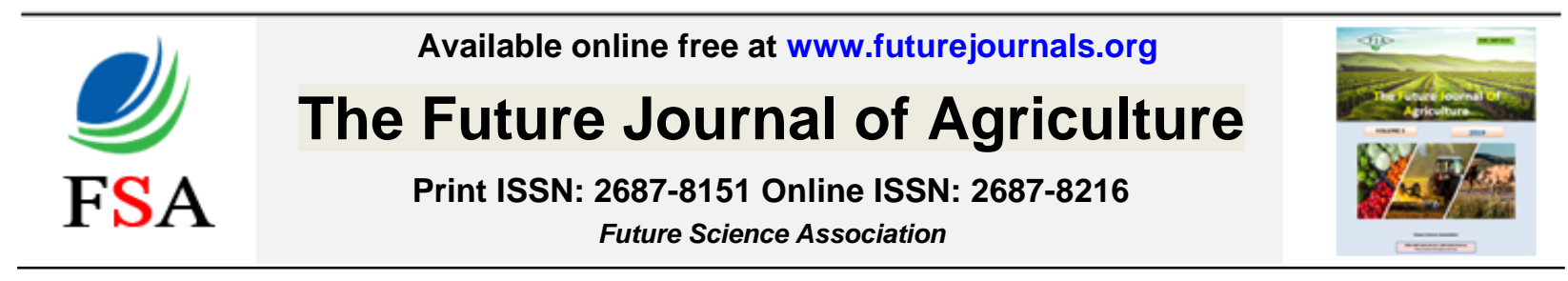

Future J. Agric., 3 (2020) 16-31

OPEN ACCES

DOI: $10.37229 /$ fsa.fja.2020.07.10

\title{
PHYSIOLOGICAL AND BIOCHEMICAL RESPONSE OF Phoenix dactylifera L. HAYANI cv. EMBRYOGENIC CALLUS AND SOMATIC EMBRYOS TO SALT STRESS UNDER IN VITRO CONDITIONS
}

\author{
Rasha, N. Arafa ${ }^{1, *}$; Ghada, A. Ali1 and Sayed, A. A. Elsayh ${ }^{2}$ \\ ${ }^{1}$ Central Lab of Date Palm Researches and Development, Agricultural Research Center, Giza, Egypt. \\ ${ }^{2}$ Agricultural Research Centre, Horticulture Institute, Department Breeding, ARC, Egypt.
}

*Corresponding author: rashanagyarafa@gmail.com Received: 10 June. 2020 ; Accepted: 10 July 2020

\begin{abstract}
Salinity stress as a major abiotic stress has influenced more than $6 \%$ of the world land which is increasing daily due to climate changes. The effect of salinity on callus regeneration and organogenesis of date palm was tested under in vitro conditions. This study was conducted to investigate the effect of salt stress on callus proliferation, somatic embryo formation of 'Hayani' date palm in vitro. The embryogenic callus was subjected to MS medium with BA at $0.05 \mathrm{mg} / \mathrm{l}$ and NAA at $0.1 \mathrm{mg} / \mathrm{l}$ supplied with different sodium chloride $(\mathrm{NaCl})$ concentrations $(0,500,1000,1500$ and $2000 \mathrm{ppm})$ for 2 subcultures. Salinity affects several physiological and biochemical processes. The investigated parameters include embryogenic callus growth, differentiation to form somatic embryos, fresh weight of both callus and embryos, biochemical analysis such as total carbohydrates, proline, protein content and minerals in embryogenic callus and somatic embryos. Low levels of abiotic stress factors can induce favorable responses in the growth and differentiation. However, high levels are detrimental resulting in reduced growth and some cell death. The callus fresh weight and the number of embryos were enhanced by adding 500 and $1000 \mathrm{ppm} \mathrm{NaCl}$ to the proliferation medium; higher salt concentrations affected the callus regeneration negatively, where at $2000 \mathrm{ppm} \mathrm{NaCl}$ the less somatic embryos were formed. High concentrations of $\mathrm{NaCl}(1500$ and $2000 \mathrm{ppm})$ decreased total soluble carbohydrates in both embryogenic callus and somatic embryos, proline content increased gradually as the external concentration of $\mathrm{NaCl}$ increased and the protein content decreased in both embryogenic callus and somatic embryos with the increase of $\mathrm{NaCl}$ concentration in culture media to $2000 \mathrm{ppm}$. Salinity inhibits water uptake and increases the concentration of toxic ions such as $\mathrm{Na}^{+}$and reduced the $\mathrm{K}^{+}$content. Tissue culture with the use of this technique would allow selection for salt tolerance in the date palm. In fact, somatic embryos subjected to 500 and 1000 ppm $\mathrm{NaCl}$ concentrations were successfully regenerated into plantlets.
\end{abstract}

Key words: Date palm, Hayani cv., in vitro, salinity stress, physiological and biochemical analysis.

\section{INTRODUCTION}

Date palm (Phoenix dactylifera L.), a monocotyledonous dioecious plant, is one of the most cultivated palms around the world (Abass, 2013). Date palm trees are cultivated in different regions worldwide, especially in the Middle East, North Africa, North and South America, Southern Europe, Pakistan and India (Al-Shahib and Marshall, 2003; Al-Khayri et al., 2015). Date palm grows very well under adverse conditions especially in arid and semiarid regions and produces highly valued date fruits. Date palm fruit is rich in carbohydrates and nutrients. It contains sugars in mostly inverted form, dietary fiber, high levels of essential amino acids and minerals (El-Far et al., 2016).

Propagation through offshoots is slow technique, limited number of offshoots, survival of low life and the risk of disease transmission rate (AlKhalifah and Askari, 2011). Propagation of date palm via in vitro culture using shoot tip explants provides effective substitution to traditional methods (Quiroz-Figueroa et al., 2006). Somatic embryogenesis is the common method used for in vitro propagation of date palm (Abahmane, 2013) depending on the development of callus and 
increases its ability to multiply and quickly differentiate into shoots; the somatic embryogenesis is widely used commercially for propagating date palm plantlets. (McCubbin et al., 2000 and AlKhayri, 2013). Tissue culture techniques have become an ideal method to produce large number of date palm plantlets (Jain, 2007). In vitro technology was used extensively in physiological studies of the mechanisms of stress tolerance and resistance of plants (Jasim et al., 2016).

Salinity stress is one of the most significant environmental stresses limiting agricultural production worldwide; and affects the anatomical, physiological and enzymatic features of plants (Arslan et al., 2016 and Nawaz et al., 2016). Salinity affects several physiological and biochemical processes; there are two types of effects, first the adverse osmotic effect, which is the presence of high concentrations of salts in the soil solution making it harder for roots to extract water and reducing the ability of the plant to take it up, leading to slower growth (Munns and Tester, 2008). Osmotic stress delays the growth of plant and affects cell division and elongation. The division of cells is crucial processes which determine the meristem activity and the overall plant growth rate (Bartels and Sunkar, 2005). Secondly, the toxicity effects, which are the presence of high concentrations of salt in the plant which can be toxic and lead to cellular damage (Munns, 2005). The salinity stress causes a negative impact on plant physiology including reduced photosynthetic capacity, impaired signaling and alterations to cellular metabolism (Munns and Tester, 2008). To understand the effect of salinity on the behavior of date palm in vitro culture, several studies have been conducted (Al-Khayri and Al-Bahrany, 2004; AlBahrany and Al-Khayri, 2012; Al-Khayri and Ibraheem, 2014). Responses of date palm in vitro to salt stress by using different concentrations of $\mathrm{NaCl}$ and the positive effect of $\mathrm{NaCl}$ at low concentration $(25 \mu \mathrm{M})$ on the proliferation of shoot tip derived callus was examined. Accumulation of proline in callus tissue date palm cultured under salt stress has been noted with stress tolerance (AlKhayri, 2002). Under stress the proline acts as an alternative resource for carbon and nitrogen, helps reducing oxidative damages and stabilizing DNA and membrane protein (Szabados and Savoure, 2010).

The aim of this study was to determine the effect of different concentrations of $\mathrm{NaCl}$ on growth, development and differentiation of in vitro embryogenic callus of Date Palm Hayani cv. and find out the effect of salt stress on the biochemical content of embryogenic callus and somatic embryos of date palm as well as, their content from total carbohydrate, total proline, total protein and minerals.

\section{MATERIALS AND METHODS}

This study was conducted in The Central Lab of Date Palm for Researches and Development Agricultural Research Center, Egypt during the period from 2017 to 2018 .

\section{Offshoot preparation}

The date palm offshoots Hayani cv. about 3-4 years old and weighing $5-7 \mathrm{~kg}$ were separated from healthy mother trees from date palm orchard in (Sakara), Giza governorate, Egypt. The shoot tips were washed with distilled water to eliminate any organic ruins then soaked in Benlate $1 \mathrm{~g} / \mathrm{l}$ fungicide solution for $10 \mathrm{~min}$ and rinsed three times with sterile distilled water. The offshoots were thoroughly cleaned and the outer leaves were removed to expose the shoot tip under aseptic condition, the shoot tips separated and immersed in antioxidant solution (150 mg citric acid and $100 \mathrm{mg}$ ascorbic acid). Shoot tips were surface sterilized with $70 \%$ ethanol for $1 \mathrm{~min}$ followed by sodium hypochlorite treatment $(60 \% \mathrm{v} / \mathrm{v}$ Clorox solution) containing 2 drops of tween 20 for 25 min after that washed three times with sterile distilled water, soaked in $0.2 \%$ $\mathrm{HgCl}_{2}$ solution for $5 \mathrm{~min}$. The shoot tips were then rinsed thoroughly with sterile distilled water, as shown in Fig. 1 (A). All leaf primordial were removed except 2 pairs surrounding the apical meristems and shoot tip was cut into 6 equal segments, then instantly moved to a prepared culture medium.

\section{Initiation stage}

For callus culture initiation, the pieces of shoot tips were cultured into callus induction medium consisting of MS salts (Murashige and Skooge, 1962) supplemented with $\mathrm{Na}_{2} \mathrm{H}_{2} \mathrm{PO}_{4}(170.0 \mathrm{mg} / \mathrm{l})$, myo-inositol $(100.0 \mathrm{mg} / \mathrm{l})$, glutamine $(200.0 \mathrm{mg} / \mathrm{l})$, nicotinic acid $(0.5 \mathrm{mg} / \mathrm{l})$, pyridoxine- $\mathrm{HCl}(0.5 \mathrm{mg} / \mathrm{l})$, thiamine $(1.0 \mathrm{mg} / \mathrm{l})$, sucrose $(40.0 \mathrm{mg} / \mathrm{l})$, agar $(6.0$ $\mathrm{g} / \mathrm{l})$ and $0.5 \mathrm{~g} / \mathrm{l}$ of activated charcoal. Plant growth regulators were added as per requirement for each in vitro stage.

For initiation stage, MS growth medium supplemented with $10.0 \mathrm{mg} / \mathrm{l}$ of 2,4dichlorophenoxy acetic acid (2,4-D), $3.0 \mathrm{mg} / \mathrm{l}$ of isopentenyl adenine (2ip) and the medium was adjusted to a pH of 5.7 and autoclaved. Explants were cultured on this medium and incubated in dark culture room at $25 \pm 2{ }^{\circ} \mathrm{C}$ for 4 months (four subcultures) to improve the initiation of callus during this period explants were re-cultured on the same medium each 4 weeks. Explants swell during the second subculture. After 4 months from culture the callus was initiated and the resultant callus 
was transferred to callus proliferation medium, as shown in Fig. 1 (B, C).

\section{Callus formation stage}

The concentration of 2,4-D was reduced gradually to enhance the proliferation callus as shown in Table 1. The explants were cultured on MS medium having 2,4-D at $5.0 \mathrm{mg} / 1$ mixed with $2 \mathrm{ip}$ at $3.0 \mathrm{mg} / \mathrm{l}$ for three subcultures. After that the callus was transferred to embryogenic callus medium which consist of MS basal medium supplemented with $2,4-\mathrm{D}$ at $3.0 \mathrm{mg} / \mathrm{l}$ with $2 \mathrm{ip}$ at 1.0 $\mathrm{mg} / \mathrm{l}$ to produce the embryogenic callus, as shown in Fig. 1 (D).

All cultures were incubated in the growth room at $25 \pm 2^{\circ} \mathrm{C}$ for 3 months (three subcultures) at total darkness. Explants or calli were recultured on the same medium each for 4 weeks. Thereafter, embryogenic callus was maintained on callus maintenance medium which consists of MS basal medium supplemented with BA at $0.05 \mathrm{mg} / \mathrm{l}+$ NAA at $0.1 \mathrm{mg} / \mathrm{l}$. These cultures served as a callus source for the salt induced stress study.

Table 1. Plant growth regulators were requirement for date palm in vitro culture stages

\begin{tabular}{ccccc}
\hline \multirow{2}{*}{$\begin{array}{c}\text { Plant growth } \\
\text { regulators }\end{array}$} & \multicolumn{4}{c}{ Callus induction } \\
\cline { 2 - 5 } & $\begin{array}{c}\text { Callus } \\
\text { initiation }\end{array}$ & $\begin{array}{c}\text { Callus } \\
\text { proliferation }\end{array}$ & $\begin{array}{c}\text { Embryogenic } \\
\text { callus }\end{array}$ & $\begin{array}{c}\text { Callus } \\
\text { maintained }\end{array}$ \\
\hline $\mathbf{2 , 4 - D}$ & $10 \mathrm{mg} / \mathrm{l}$ & $5 \mathrm{mg} / \mathrm{l}$ & $3 \mathrm{mg} / \mathrm{l}$ & - \\
$\mathbf{2 i P}$ & $3 \mathrm{mg} / \mathrm{l}$ & $3 \mathrm{mg} / \mathrm{l}$ & $1 \mathrm{mg} / \mathrm{l}$ & - \\
$\mathbf{B A}$ & - & - & - & $0.05 \mathrm{mg} / \mathrm{l}$ \\
NAA & - & - & - & $0.1 \mathrm{mg} / 1$ \\
\hline
\end{tabular}
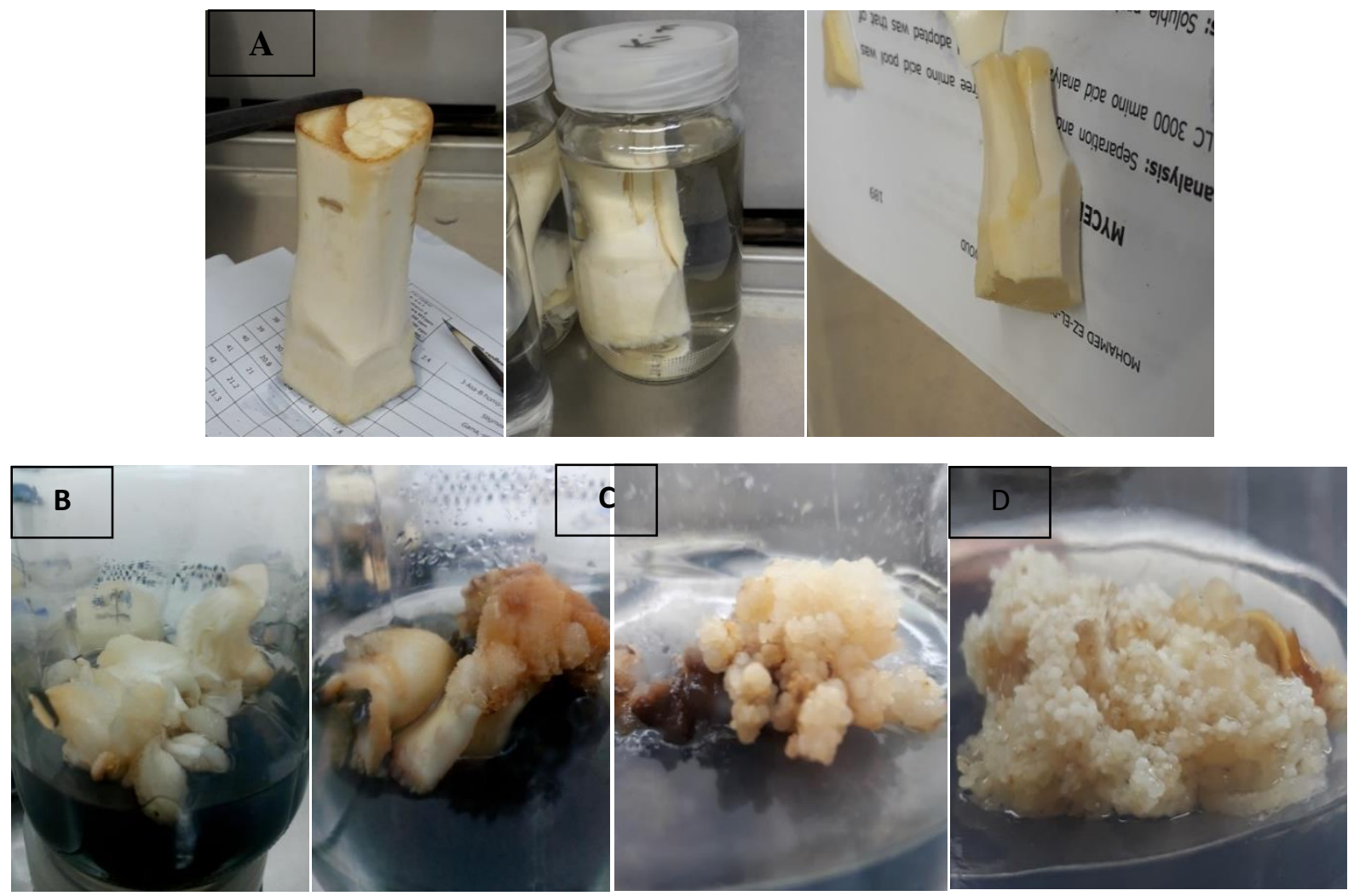

Fig. 1. Different stage of in vitro date palm Hayani cv., A: Offshoot preparation, B: swelling stage, C: callus formation stage, D: Embryogenic callus formation 


\section{Salinity stress}

The embryogenic callus was used to begin in vitro salt tolerance experiments. For that we used MS basal nutrient medium supplemented with BA at $0.05 \mathrm{mg} / \mathrm{l}+\mathrm{NAA}$ at $0.1 \mathrm{mg} / \mathrm{l}$ with the addition of different concentrations of $\mathrm{NaCl}(0,500,1000,1500$ and $2000 \mathrm{ppm}$ ) with five replicates. Cultures were incubated in complete darkness at $25 \pm 2^{\circ} \mathrm{C}$ for 8 weeks (two subcultures). Each treatment consisted of 8 cultures containing about $0.5 \mathrm{~g}$ embryogenic callus/jar.

\section{a. Physiological traits}

After the incubation period, all exposed callus was analyzed to determine their responses to salt stresses, the fresh weight of embryogenic callus was measured after 8 weeks from culture and also the number of embryos induction on callus was counted.

\section{b. Biochemical analyses}

Chemical analyses were done for embryogenic callus and somatic embryos including the following:

\section{Determination of total carbohydrates}

The total carbohydrates were determined in the embryogenic callus and somatic embryos of date palm according to the method of Watanabe $\boldsymbol{e t} \boldsymbol{a l}$. (2000) using a spectrophotometer which measure absorption spectrum at wave length of $620 \mathrm{~nm}$ and standard curve of glucose was made for calculation.

\section{Determination of proline}

Proline content was determined by a spectrophotometric assay as described by Bates $\boldsymbol{e t}$ al. (1973).

\section{Determination of total soluble protein}

The method of Bradford (1976) was followed to measure the total soluble protein, Albumin was used to make a standard curve and absorbance measured at $595 \mathrm{~nm}$.

\section{Mineral analysis}

The $\mathrm{Na}^{+}$and $\mathrm{K}^{+}$concentration in the treated calli were measured based on the method described by Skoog et al. (2007) using Jenway Model PEP7 flame photometer.

\section{Embryos culture}

After the experiment of salt stress, the embryo clusters were derived from callus cultures and transferred to fresh medium without $\mathrm{NaCl}$ consists of $3 / 4 \mathrm{MS}$ basal medium supplemented with $30 \mathrm{~g} / \mathrm{l}$ sucrose, $0.1 \mathrm{mg} / \mathrm{l} \mathrm{NAA}$ and $0.05 \mathrm{mg} / \mathrm{l} \mathrm{BA}$ (Ibrahim et al., 2009) for continued embryo proliferation. The somatic embryo cultures were incubated in growth room at $26 \pm 2{ }^{\circ} \mathrm{C}$ with light conditions 16-h photoperiods, and recultured to the same fresh medium for two subcultures ( 8 weeks) to increase mass production of somatic embryos and germination.

\section{Shoot elongation and rooting stage}

Regeneration shoots were transferred to the $3 / 4$ MS medium supplemented with $0.5 \mathrm{mg} / 1$ gibberellic acid $\left(\mathrm{GA}_{3}\right)+1.0 \mathrm{mg} / \mathrm{l}$ NAA to obtain shoot elongation and root formation (AL-Mayahi, 2015). The cultured jars were incubated at $25 \pm 2{ }^{\circ} \mathrm{C}$ with light intensity 3000 lux for $16 \mathrm{~h}$ photoperiod in the growth room for 8 weeks and each 4 weeks the shoots were transferred to the same fresh medium. To enhance root formation, for two month (two subculture) the healthy regenerated plantlets were cultured on $1 / 2$ MS medium supplemented with 0.1 $\mathrm{mg} / \mathrm{l}$ IBA, $1.5 \mathrm{~g} / \mathrm{l}$ activated charcoal and $30 \mathrm{~g} / \mathrm{l}$ sucrose (Eke $\boldsymbol{e t}$ al., 2005) and incubated under the same conditions as described above.

\section{Statistical analysis}

This experiment was designed as a randomized complete block design as described by (Gomez and Gomez, 1984). The obtained data were statistically analyzed using MSTAT Computer Program (MSTAT Development Team, 1989). To verify differences among means of various treatments, means were compared using Duncan's Multiple Range Test as described by (Duncan, 1955).

\section{RESULTS AND DISCUSSION}

\section{Effect of salinity on callus fresh weight (g)}

The embryogenic callus continued to grow normally without any sign of cell dehydration or salt induced damage showed tolerance to the lower concentration of $\mathrm{NaCl}$ added to the culture medium. This may point to the suitability of the osmotic potential of the medium for date palm callus growth and the best proliferation (Al-Mansoori et al., 2007).

Results presented in Table 2 and Fig. 2 show the effect of $\mathrm{NaCl}$ concentration on fresh weight of embryogenic callus. Callus fresh weight was determined after 8 weeks in salt treatments. The results showed a gradual decrease in fresh weights with an increase in salt concentration over 1000 ppm of $\mathrm{NaCl}$ as compared to the control treatment. Salt concentrations at 500 and 1000 ppm gave the highest fresh weight reached 4.84 and $4.79 \mathrm{~g}$, 
respectively compared with control treatment $3.22 \mathrm{~g}$ and significant difference with all treatments. Also, there was a significant decrease in fresh weight at concentrations of 1500 and $2000 \mathrm{ppm}$ and the lowest fresh weight was recorded with concentration of 2000 ppm reached $1.82 \mathrm{~g}$ which differed significantly with control and all other treatments.

Perhaps low $\mathrm{NaCl}$ concentrations (500 and 1000 ppm) are optimal for the growth of the embryogenic callus and somatic embryos. It may also be the reason behind the significant enhancement of its fresh weight due to the maximum possible absorption of water and essential mineral elements by cells as a means of resistance to salt stress conditions (Rains et al., 1986). It was found that using $\mathrm{NaCl}$ at concentrations of $25-50 \mu \mathrm{M}$ caused a significant increase in callus fresh weight of other date palm cultivars Barhee and Helali (Al-Khayri, 2002).

But the reduction in callus fresh weight at high salt stress $2000 \mathrm{ppm}$ may be attributed to the negative effect of salt on cells grown at high salt concentrations. This finding was similar with previous reports under in vitro salinity stress (AlKhayri, 2002; Queiros et al., 2007; Rafiq et al., 2008; Lokhande et al., 2011 and Golkar et al., 2017).

There was a significant decrease in fresh weight of callus with high concentration of $\mathrm{NaCl}$ at 320 $\mu \mathrm{M}$. The effect on growth is probably due to osmotic effect and ion cytotoxicity, due to the accumulation of $\mathrm{Na}^{+}$and $\mathrm{Cl}^{-}$leading to growth inhibition. It has been suggested that the reduction of growth in response to salinity is the result of great portion of respiratory energy being transferred to processes resulting in salt tolerance rather than growth (Mass, 1986). Data indicated the passive effect of $\mathrm{NaCl}$ treatments on callus growth and frequency of somatic embryo germination percentage after 12 weeks. The Highest value of callus growth (1.93 and $2.00 \mathrm{~g}$ ) was observed at $50 \mu \mathrm{M} \mathrm{NaCl}$ compared to control treatment (1.98 and $2.05 \mathrm{~g})$, following by $100 \mu \mathrm{M}$ (1.47 and $1.90 \mathrm{~g}), 200 \mu \mathrm{M}$ (1.25 and 1.49 $\mathrm{g}), 300 \mu \mathrm{M}$ (0.24 and $0.45 \mathrm{~g}$ ) for cv. Barhi and cv. Khalas, respectively although callus of cv. Khalas recorded the minimum value of callus growth $(0.13$ g) under $400 \mu \mathrm{M} \mathrm{NaCl}$ (Al-Dhebiani et al., 2018). Adding $\mathrm{NaCl}$ to callus culture of $N$. sativa results in reducing the callus growth from control $(0.17 \mathrm{~mm})$ to $(0.068 \mathrm{~mm})$ significantly in the treatment with $250 \mu \mathrm{M} \mathrm{NaCl}$ under in vitro salt stress. In addition, salinity stress represents a negative osmotic stress, leading to a decrease in the water available in the callus cells, which consumes energy leading to the reduced growth of callus (Golkar et al., 2019). Salinity stress could reduce the plant productivity by unbalancing cellular ions (Tester and Davenport, 2003). It had been previously observed by many workers that the presence of salt in the medium generally reduced or even completely inhibited the plant regeneration (Lutts et al., 1999).

\section{Effect of salinity on somatic embryos induction}

There was a significant difference between different concentrations of $\mathrm{NaCl}$ and the number of somatic embryos. The number of somatic embryos of Hayani cv. was enhanced in response to low level of salinity as $\mathrm{NaCl}$ at 500 and 1000 ppm which resulted in the increase in the number of somatic embryos 12.45 and 11.60 embryo/jar, respectively compared with the control treatment which recorded low number of embryos 5.13 embryo/jar. However, increasing the concentration of $\mathrm{NaCl}$ over $1000 \mathrm{ppm}$ decreased the number of embryos gradually; it was reduced from 6.29 to 4.03 embryos/jar with the treatments 1500 and $2000 \mathrm{ppm} \mathrm{NaCl}$, respectively as shown in Table 2 and Fig. 2.

Table 2. Effect of $\mathrm{NaCl}$ concentrations on fresh weight of embryogenic callus and number of somatic embryos of the date palm Hayani cv. after 8 weeks from culture

\begin{tabular}{ccc}
\hline $\begin{array}{c}\text { NaCl concentration } \\
(\mathbf{p p m})\end{array}$ & $\begin{array}{c}\text { Fresh weight (g) of embryogenic } \\
\text { callus }\end{array}$ & Number of somatic embryos \\
\hline $\mathbf{0}$ & $3.22 \mathrm{~b}$ & $5.13 \mathrm{~b}$ \\
$\mathbf{5 0 0}$ & $4.84 \mathrm{a}$ & $12.45 \mathrm{a}$ \\
$\mathbf{1 0 0 0}$ & $4.79 \mathrm{a}$ & $11.60 \mathrm{a}$ \\
$\mathbf{1 5 0 0}$ & $2.47 \mathrm{c}$ & $6.29 \mathrm{c}$ \\
$\mathbf{2 0 0 0}$ & $1.82 \mathrm{~d}$ & $4.03 \mathrm{~d}$ \\
\hline
\end{tabular}



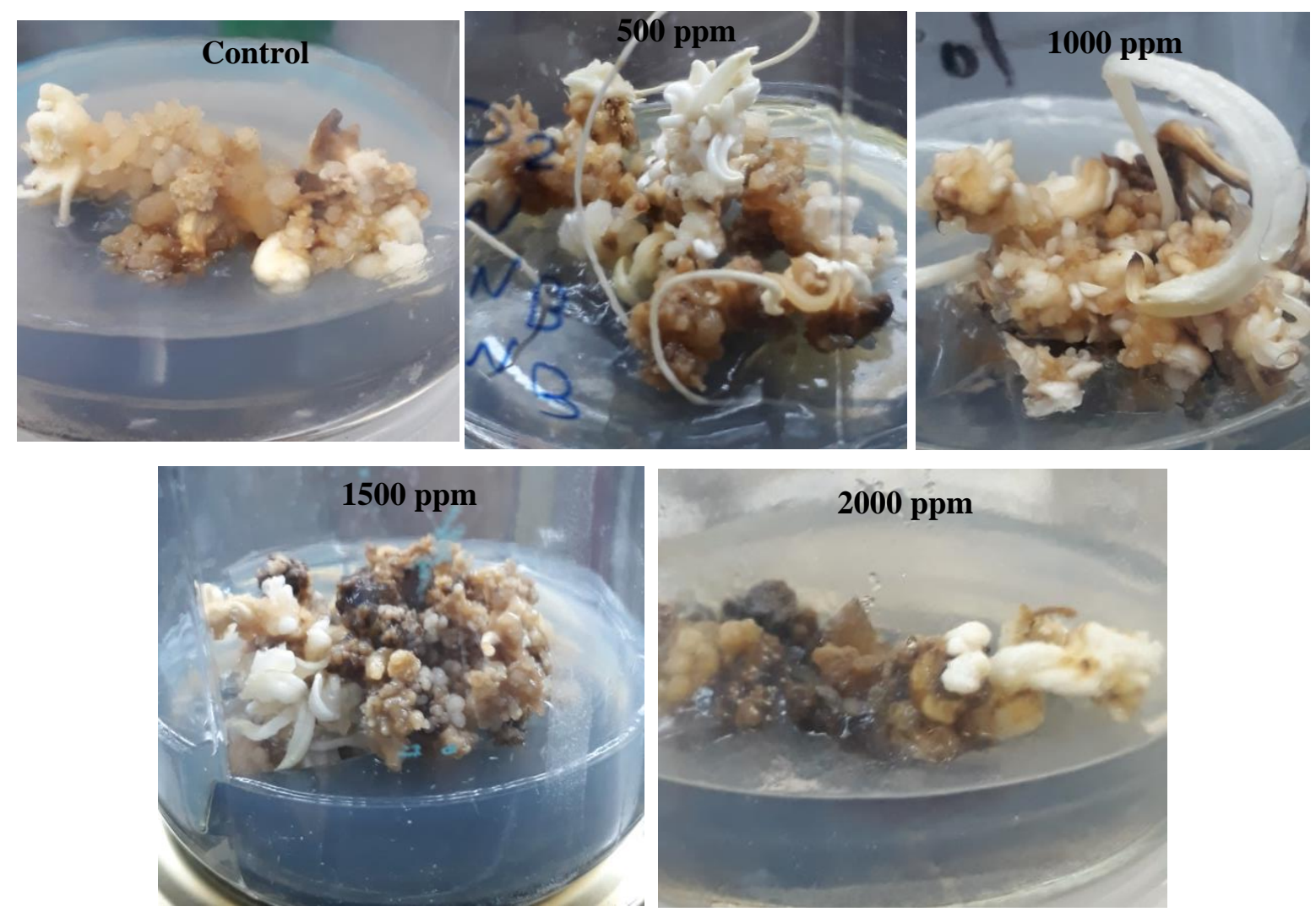

Fig. 2. The growth of embryogenic callus and somatic embryos of date palm Hayani cv. under salinity conditions by treatment with different concentrations of $\mathrm{NaCl}$

These results were in agreement with several studies, low levels of salinity can enhance growth and development of in vitro date palm callus culture (Al-Khayri, 2002). Moreover, the number of somatic embryos of cv. Zagloul was enhanced in response to low concentration $(25 \mu \mathrm{M})$ of $\mathrm{NaCl}$. However, higher concentrations of $\mathrm{NaCl}$ reduced callus growth and the number of somatic embryos (Ibraheem et al., 2012). In addition, using of seawater in all in vitro culture stages, proved to be highly effective for enhancing somatic embryogenesis of cv. Malkaby (Taha, 2014). According to Ibraheem et al. (2012) the number of somatic embryos of cv. Zaghloul was enhanced with adding $25 \mu \mathrm{M} \mathrm{NaCl}$ to the regeneration medium; however, at $75 \mu \mathrm{M} \mathrm{NaCl}$ the number of resultant somatic embryos was reduced and no embryo formed at $175 \mu \mathrm{M} \mathrm{NaCl}$.

The results showed that increasing $\mathrm{NaCl}$ concentration significantly decreased the fresh weight of both the embryogenic callus and somatic embryos (Abbas et al., 2012). The addition of $\mathrm{NaCl}$ to the media caused a significant effect on the reduction of somatic embryo germination percentage (Al-Zubaidi et al., 2013 and Ibraheem, 2013). Adverse effect was reported by Jasim et al. (2010) where $0.5-2.0 \% \mathrm{NaCl}$ inhibited callus growth and somatic embryogenesis of cv. Ashkar. The presence of salt in culture medium resulting in the loss of regeneration in organogenic callus and shoots were obtained from culture media with $42.7 \mathrm{~mm}$ and $85.57 \mathrm{~mm} \mathrm{NaCl}$ (Sharry and Teixeira da Silva, 2006). Date palm regeneration through somatic embryogenesis is affected by the salt concentration of the culture medium. A low concentration of salt $(0.4 \% \mathrm{NaCl})$ observed to increase the length of in vitro shoots of cvs. Bartamuda, Sewy and Samani. However, shoot growth reduction was noticed at $0.8 \%$ and $1.2 \% \mathrm{NaCl}$ (El-Sharabasy et al., 2008).

\section{Chemical analysis}

Plant acclimation under abiotic stresses such as salinity has been examined through biochemical analysis. There is much studies of embryos subjected to salt treatment (Munns, 2002 and Santos et al., 2011). The tolerant cells make osmotic adjustments in response to abiotic stress; such as, highly soluble compounds like sugars, amino acids and proline accumulate in higher plants under salinity stress (Ashraf, 1994). They serve as organic compatible solutes, which cause osmotic adjustments and play a role in stabilization of proteins, protection of membrane and help in regulating ionic sequestration (Patade $\boldsymbol{e t}$ al., 2011). 


\section{Determination of total carbohydrates}

Data in Fig. 3 revealed that, there was a significant difference between different concentrations of $\mathrm{NaCl}$ and total carbohydrate content in the embryogenic callus. Added $\mathrm{NaCl}$ to culture medium at concentration $500 \mathrm{ppm}$ increased the carbohydrate content $(21.80 \mathrm{mg} / \mathrm{g} \mathrm{fw})$ in the embryogenic callus compared with the control treatment $(20.16 \mathrm{mg} / \mathrm{g} \quad \mathrm{fw})$. Increasing $\mathrm{NaCl}$ concentration to $1000 \mathrm{ppm}$ increased total carbohydrate content to $(22.5 \mathrm{mg} / \mathrm{g} \mathrm{fw})$; however, increasing the concentration of salinity stress over $1000 \mathrm{ppm}$ to $1500 \mathrm{ppm}$ was resulted reduced the total carbohydrate content to $(20.00 \mathrm{mg} / \mathrm{g} \mathrm{fw})$.
While, the lowest carbohydrate content $(17.30 \mathrm{mg} / \mathrm{g}$ fw) was recorded at the highest concentration of $\mathrm{NaCl}$ at $2000 \mathrm{ppm}$.

There was significant difference between different concentrations of $\mathrm{NaCl}$ and total carbohydrate content in the somatic embryos. The highest total carbohydrate content (20.76 and 21.60 $\mathrm{mg} / \mathrm{g} \mathrm{fw})$ was recorded with the concentration of $\mathrm{NaCl}$ at 500 and $1000 \mathrm{ppm}$ compared with the control treatment which was $(19.20 \mathrm{mg} / \mathrm{g} \mathrm{fw})$. The content of carbohydrate was reduced due to increasing the salinity concentration to 1500 and $2000 \mathrm{ppm}$ and recorded (18.62 and $16.80 \mathrm{mg} / \mathrm{g} \mathrm{fw}$ ), respectively.

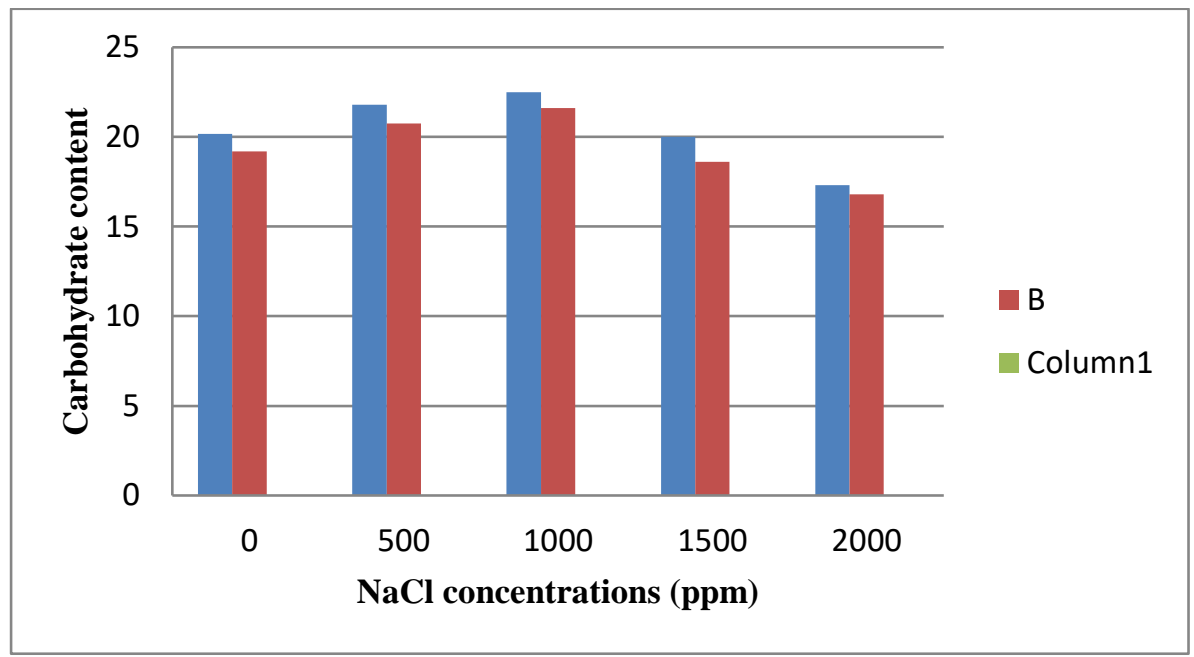

Fig. 3. Effect of different concentrations of $\mathrm{NaCl}$ on carbohydrate content $(\mathrm{mg} / \mathrm{g}$ fw) in embryogenesis callus (A) and somatic embryos (B) after 8 weeks in culture

These results were in agreement with (Mehr, 2013) who reported the increase in the amount of production of some compounds in plants as exposure to salt stress and this is one of the mechanisms by which plants resist salt stress examples of such compounds are carbohydrates. Jasim et al. (2010) also found that an increase of $\mathrm{NaCl}$ concentrations in the medium led to a decrease of total soluble carbohydrates and proteins of embryogenic callus and somatic embryos of date palm, but it increased free proline.

The decrease in carbohydrates under salt stress condition might be related to the salt stress that make cells spend more energy for osmoregulation to endure the turbulence caused by salt accumulation inside cells, also high salt condition increase respiration rate through the effect of sodium ions on respiration cycle that led to the decrease in carbohydrates (Wang et al., 1999 and Huang and Liu, 2002). Salinity induced soluble sugar accumulation has also been observed in $P$. euphratica (Watanabe et al. 2000; Zhang et al.
2004). The best characterized biochemical response of plant cells to osmotic stress is accumulation of some compatible organic solutes like soluble sugars (Flowers and Colmer, 2008). The results showed clearly that salinity significantly inhibited fresh weight of the callus of Citrus sinensis and decreased the concentration of carbohydrates (Abbas et al., 2013). The carbohydrate concentration of Salsola arbuscula callus increased with used $300 \mu \mathrm{M}$ of $\mathrm{NaCl}$, but decreased significantly in the $400 \mu \mathrm{M}$ of $\mathrm{NaCl}$ (Amini et al., 2017).

Salinity also induces oxidative stress, which influences enzyme activity causing a reduction in carbohydrate metabolism (Huang and Liu, 2002). It was observed that low salinity caused by $\mathrm{NaCl}$ at 10 $\mu \mathrm{M}$ significantly increased total soluble carbohydrate in plantlet leaves as reported by AlKabi (2004) for date palm. As the concentration of $\mathrm{NaCl}$ increased, the concentration of soluble carbohydrates was significantly decreased. The salt tolerant callus of sugarcane accumulated more soluble sugars under $\mathrm{NaCl}$ stress (Gandonou et al., 
2006). However, the soluble sugars did not accumulate in calli from salt-resistant wheat $\mathrm{cv}$. Belikh (Lutts et al., 2004). Increasing seawater levels increased total soluble sugars content compared with the control. Total soluble sugars in leaves of two young Iranian commercial olive cultivars increased with an increase in salinity up to $80 \mu \mathrm{M}$ but decreased with additional increase in salinity (Mousavi et al., 2008). In addition, soluble carbohydrate concentration of two sugar beet cultivars significantly increased with increasing salt stress. Palma et al. (2009) suggested that the response to salinity $(100 \mu \mathrm{M} \mathrm{NaCl})$ was improved by increasing plant dry weight and decreasing the contents of organic solutes like total soluble sugar contents in Phaseolus vulgaris L. Dhanapackiam and Ilyas (2010) reported that the increase of total carbohydrates in the shoot is considered to be playing an important role in the osmotic adjustment. To evaluate osmotic adjustment of the callus, the contents of soluble sugar were determined. The soluble sugar contents were increased by 1.6 -fold under $50 \mu \mathrm{M} \mathrm{NaCl}$ and 1.8 -fold under $150 \mu \mathrm{M} \mathrm{NaCl}$ treatments. The soluble sugar content was induced in the alkaligrass calli and leaves under stresses of $\mathrm{NaCl}$ (Yu et al., 2011). The decrease in the photosynthesis rate occurred at high salinity, also inhibited cell expansion and cell division stomatal conductance and closure in Bruguiera parviflora followed by the decrease in chlorophyll and carbohydrates content (Sofy and Fouda, 2013).

\section{Determination of proline}

The data indicate that salt stress had a significant effect on proline content in embryogenic callus cultured in MS medium with different concentration of $\mathrm{NaCl}$. An increase in $\mathrm{NaCl}$ concentration cause a significant increase in proline content to $2.06 \mathrm{mg} / \mathrm{g}$ fw with adding $2000 \mathrm{ppm}$ of $\mathrm{NaCl}$ in culture medium compared with control treatment which recorded $(1.03 \mathrm{mg} / \mathrm{g} \mathrm{fw})$. Whereas low concentration of salt stress at $500 \mathrm{ppm}$ gave less proline content $(1.22 \mathrm{mg} / \mathrm{g} \quad \mathrm{fw})$ and differed significantly with control treatment and with all treatments as showed in Fig. 4.

There was a significant difference between different concentration of $\mathrm{NaCl}$ and the proline content in somatic embryos. The increase in proline content was found to be gradual with the increase of $\mathrm{NaCl}$ concentration in the culture medium. The somatic embryos grown on MS medium supplemented with 1500 and $2000 \mathrm{ppm} \mathrm{NaCl}$ showed the highest proline content (1.93 and 2.20 $\mathrm{mg} / \mathrm{g} \mathrm{fw}$, respectively) in comparison to control treatment which recorded $(1.20 \mathrm{mg} / \mathrm{g} \mathrm{fw})$, as shown in Fig. 4. The low proline content $(1.34 \mathrm{mg} / \mathrm{g} \mathrm{fw})$ resulted with low level of salt stress at $500 \mathrm{ppm}$ compared to control.

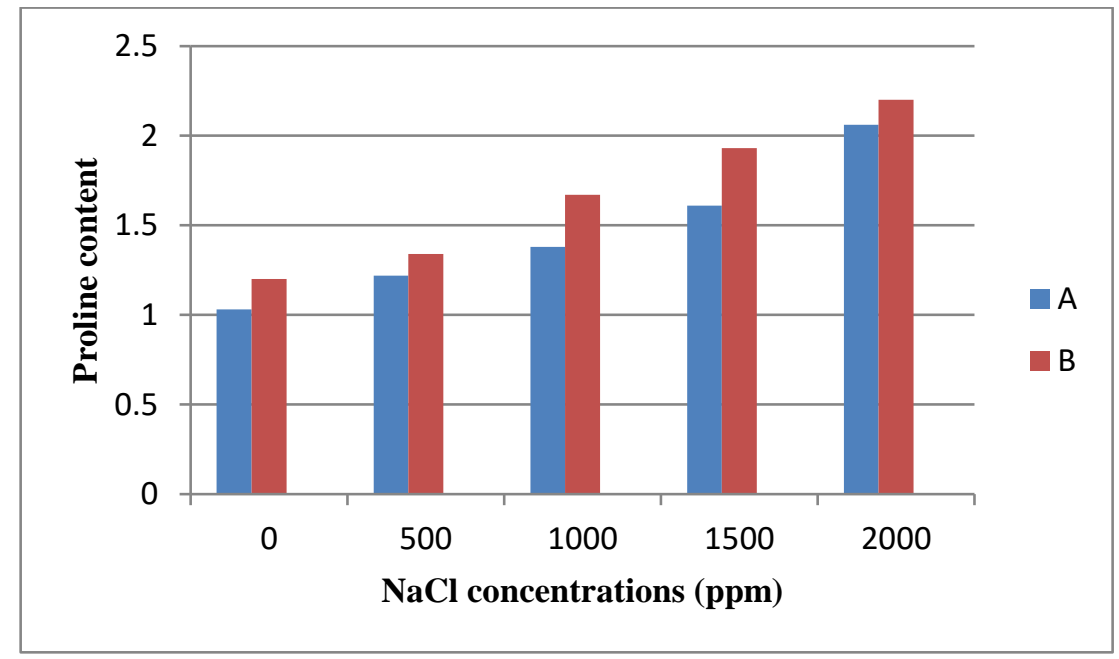

Fig. 4. Effect of different concentrations of $\mathrm{NaCl}$ on Proline content (mg/g fw) in embryogenesis callus (A) and somatic embryos (B) after 8 weeks in culture

These results agree with the results of Watanabe et al. (2000) in which salinity stress showed to increase the proline content in grape var. Khoshnaw. The highest content of free proline was obtained at the $100 \mu \mathrm{M}$ salinity level, while the lowest was recorded in the control treatment. The calli of Sesuvium portulacastrum grown on MS medium supplemented with 200 and $400 \mu \mathrm{M}$ salt showed significantly the highest proline content in comparison to control calli (Lokhande et al., 2010).

Physiological studies on callus exposed to salt stress have shown an increase in proline accumulation in response to increased salinity. Proline accumulation was correlated to callus growth inhibition (Al-Khayri, 2002) and hence is useful as a biochemical marker to understand how 
plant tolerates the abiotic stresses (El-Hadrami et al., 2011). The role of proline accumulation in tolerance to salt stress is thought to play role in osmotic phase of salt stress at early stages of salt treatment or at mild salt stress conditions (Arzani, 2008). Proline acts as osmotica that protects the cytosol from dehydration as symptomatic salt stress damage (Ashraf and Foolad, 2007). proline may act as a regulatory molecule able to activate multiple responses that are component of the adaptation process (Ashraf and Harris, 2004) and act as a osmolyte, stabilizer of the proteins structure, thereby protecting cells from damage caused by stress (Szabados and Savoure, 2010). Under salinity stress, higher levels of glutamate as a preproduct for chlorophyll and proline were consumed to generate proline (Ahmad, 2014). Proline can adjust the osmotic pressure of cells under various stresses. Additionally, free proline can remove and detoxify the reactive oxygen species (ROS) generated as a result of stresses, thus protecting cell membranes against these radicals (Saed-Moucheshi et al., 2014). The response of proline and carbohydrates to salt stress may be due to these osmoprotectants that play an important role in decreasing stress-induced cellular acidification and osmotic adjustments, stabilizes sub-cellular structures for recovery (Tan et al., 2008). In Plantago ovata callus, the proline content averaged over all the genotypes was found to increase with increasing salt from $0.1 \mathrm{mg} / \mathrm{l} \mathrm{FW}$ in control to $1.1 \mathrm{mg} / \mathrm{l} \mathrm{FW}$ in $200 \mu \mathrm{M} \mathrm{NaCl}$ (Golkar et al., 2017).

\section{Determination of total soluble protein}

There was a significant difference between different levels of $\mathrm{NaCl}$ and protein content in both of embryogenic callus and somatic embryos. Results in Fig. 5 indicated that increase in $\mathrm{NaCl}$ concentration in culture medium led to decrease in protein content in both embryogenic callus and somatic embryos especially under high level of salt stress $2000 \mathrm{ppm}$ where the protein content reached to $(0.72 \mathrm{mg} / \mathrm{g} \mathrm{fw})$ compared to $(2.10 \mathrm{mg} / \mathrm{g} \mathrm{fw})$ under control treatment for embryogenic callus. While, in somatic embryos resulted $(0.65 \mathrm{mg} / \mathrm{g} \mathrm{fw})$ at 2000 ppm salt stress compared to $(1.8 \mathrm{mg} / \mathrm{g} \mathrm{fw})$ under control treatment.

The decrease in protein content under salt stress might be related to the inhibition of protein synthesis by high salty condition (Kaouthar et al., 2001), also high salts in the culture media might inhibit absorption of necessary elements for protein synthesis such as nitrogen, besides the negative effect of salinity on the biosynthesis of mRNA which lead to the disturbance of protein synthesis (Whitting and Wilson, 2003) whereas, the increase in protein content at $20,40,60$ and $80 \mu \mathrm{M}$ may be due to stress induced synthesis of proteins (Cherian and Reddy, 2003). Proteins are a potential biochemical useful in salt resistant of plant cells and protect high plants against stresses by adjusting osmotic pressure by many compatible solutes (Shonjani, 2002).

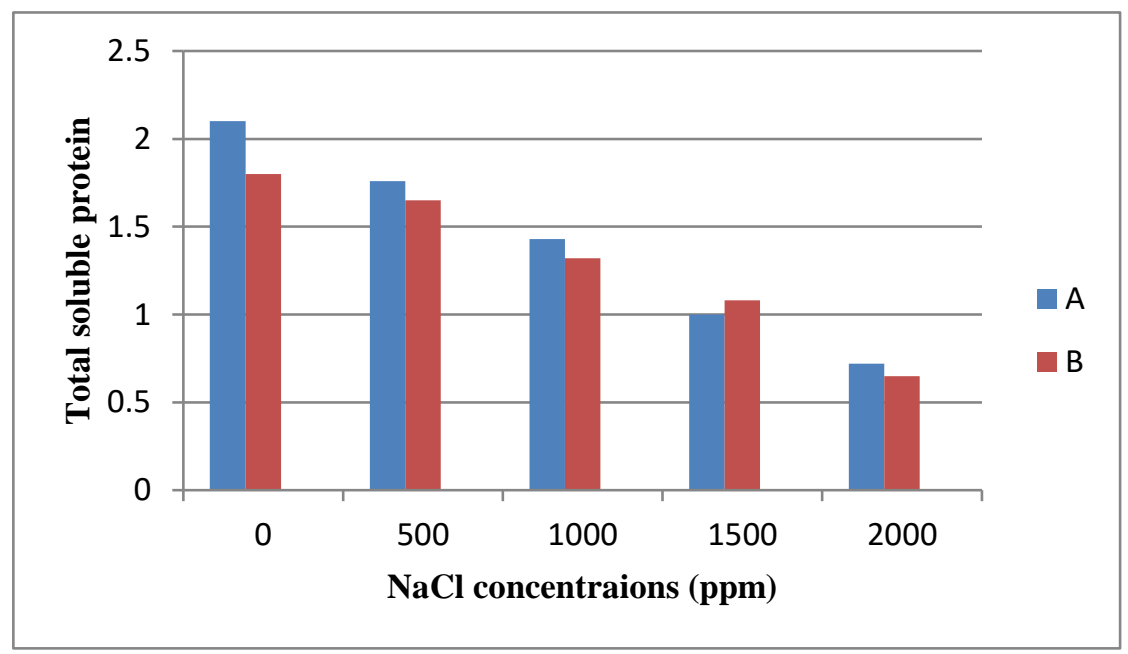

Fig. 5. Effect of different concentrations of $\mathrm{NaCl}$ on total soluble protein $(\mathrm{mg} / \mathrm{g} \mathrm{fw})$ in embryogenesis callus (A) and somatic embryos (B) after 8 weeks in culture

Rahnama and Ebrahimzadeh (2004) also observed a decrease in protein in shoots and callus of potato with increasing $\mathrm{NaCl}$ concentrations. The effects of $\mathrm{NaCl}$ treatments $(100-200 \mu \mathrm{M})$ on protein contents in potato leaves were studied by Fidalgo et al. (2004). They observed a significant decrease in protein content under salt stress.
Shankhdhar et al. (2000) indicated that total protein contents of callus cultures decreased with an increase in salt concentration after 4 weeks of culture in six cultivars of rice callus. Agastian et al. (2000) reported that soluble proteins increased at low salinity but decreased at high salinity in mulberry. Similarly, Khedr et al. (2003) also 
reported a decrease in growth and protein contents due to salt stress in the desert plant Pancratium maritimum L. Soluble protein contents of leaves were shown to have decreased in response to salinity in Oryza sativa L. (Alamgir and Ali, 1999), Raphanus sativus (Muthukumarasamy et al., 2000) and Bruguiera parviflora (Parida et al., 2002). Total protein content was significantly the highest in callus of Sesuvium portulacastrum stressed with 100 $\mu \mathrm{M} \mathrm{NaCl}$ compared to control and further decreased with increased salt concentrations (Lokhande $\boldsymbol{e t}$ al., 2010). Protein synthesis and lipid metabolism are affected under salt stress, positive antioxidant response might be responsible for a higher tolerance to stress in Carrizo citrange. The photosynthesis, respiration rate and total protein content of plants decreased under salt stress (Yaish, 2015).

In contrast to above, the increase in protein contents under salinity stress was observed with Bekheet et al. (2000) who selected two cultivars of Asparagus officinalis by culture shoot segments on callus induction medium supplemented with salt mixture. The cultivars showed better growth, high protein content, fresh and dry weight as salt concentration increased up to $6000 \mathrm{ppm}$.

\section{Minerals analysis}

In the current study, the effect of different concentrations of salinity on mineral contents in Hayani cv. was investigated. The results indicated a positive relationship between salinity levels and $\mathrm{Na}^{+}$ ion content, while on the other side there was an inverse relation between salinity level and $\mathrm{K}^{+}$ion content.

\section{Sodium ion content}

In the embryogenic callus, the $\mathrm{Na}^{+}$concentration increased significantly with increasing the concentration of $\mathrm{NaCl}$ in the culture medium, especially at the concentrations of 1500 and 2000 ppm $\mathrm{NaCl}$ which recorded (4.26 and $4.33 \mathrm{mg} / \mathrm{g} \mathrm{dw}$, respectievely) compared with the control treatment (3.42 mg/g dw) as shown in Fig. 6.

$\mathrm{Na}^{+}$concentration in the somatic embryos increased significantly with increasing salt concentration in culture medium, as shown in Fig. 6. The increase in $\mathrm{Na}^{+}$concentration was observed when the embryos were cultured on a medium containing high level of salt stress at $2000 \mathrm{ppm} \mathrm{NaCl}$ which resulted $(4.02 \mathrm{mg} / \mathrm{g} \mathrm{dw})$ compared with the control treatment $(3.13 \mathrm{mg} / \mathrm{g} \mathrm{dw})$.

This increase in $\mathrm{Na}^{+}$is due to its high concentration in the culture medium, which increases its absorption over other essential elements, such as $\mathrm{K}^{+}$. This study was confirmed with previous reports on different plant species as safflower (Golkar and Taghizadeh, 2018), sunflower (Alvarez et al., 2003) and P. ovata (Golkar et al., 2017) subjected to in vitro salinity stress. The increase in $\mathrm{Na}^{+}$concentration in other date palm cultivars has been reported by Al-Khayri (2002) and also for tomato and grapes under salt stress (El-Hammady et al., 1999). Salinity has a negative effect on growth and development of plants through the osmotic stress due to the toxic effect of sodium ion, besides the ionic imbalance induced by accumulation of this ion (Sairam and Tyagi, 2004). The callus $\mathrm{Na}^{+}$content increased with increasing salt level, whereas callus $\mathrm{K}^{+}$content decreased under the same conditions. The increase in $\mathrm{Na}^{+}$contents is possibly an osmotic adjustment mechanism, which enable the tissues to adapt to the low water potential of the external environment (Sabbah and Tal, 1990).

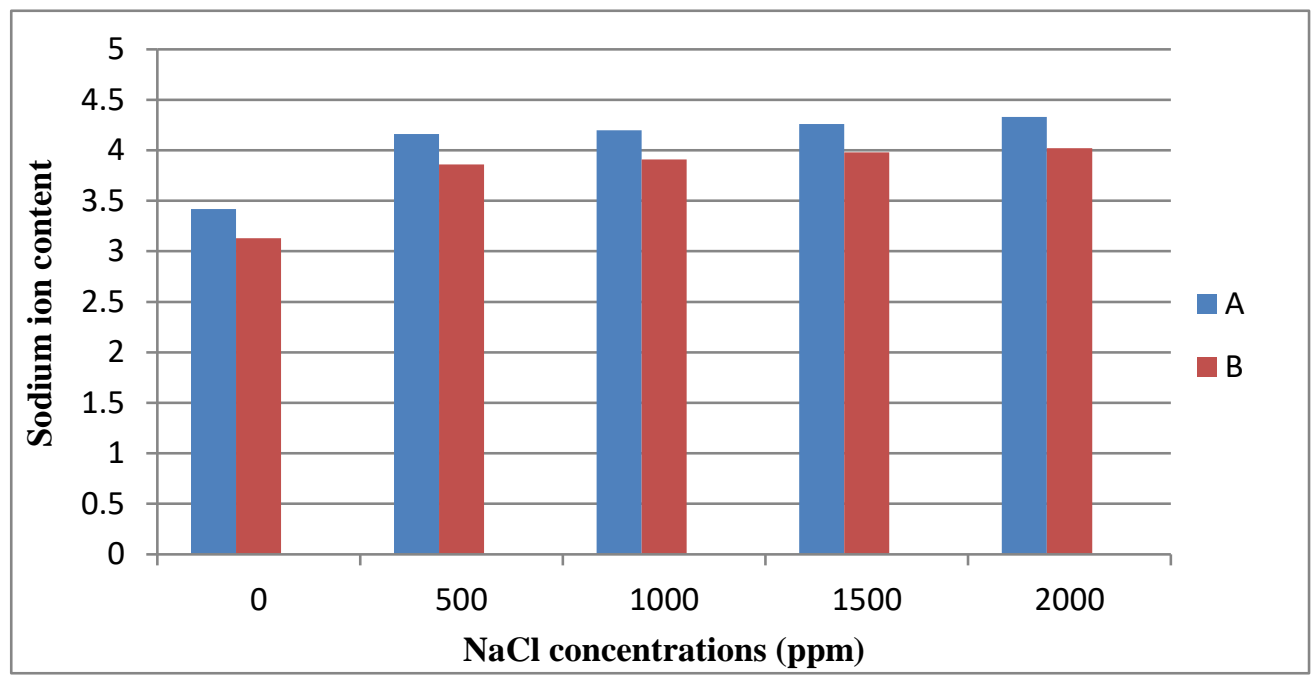

Fig. 6. Effect of different concentrations of $\mathrm{NaCl}$ on sodium ion content $(\mathrm{mg} / \mathrm{g} \mathrm{dw})$ in embryogenesis callus (A) and somatic embryos (B) after 8 weeks in culture 
Sotiropoulos et al. (2006) reported that explants are under stress in two ways under in vitro salinity by the increase of culture media osmotic potential as a result of high $\mathrm{Na}^{+}$content and by $\mathrm{Na}$ toxic effects. Also, Rus et al. (2000) studied the rising of $\mathrm{Na}^{+}$ concentration in $N$. sativa calli under salinity stress. High concentrations of sodium ions decreased osmotic balance and membrane structure, reduced growth and inhibited cell division. In addition, high concentration of $\mathrm{Na}^{+}$ion in nutritional solutions destroy hydraulic conductivity and tissue permeability related to water, thus decreasing plant survival (Abadı 'a et al., 1999). Such effect on growth is probably due to the effects of salinity, include osmotic effect and ion cytotoxicity; the accumulation of $\mathrm{Na}^{+}$and $\mathrm{Cl}^{-}$in culture cell resulted in the growth inhibition. Furthermore, it has been suggested that the reduction of growth in response to salinity is the result of great portion of respiratory energy being diverted to processes which resulted in salt tolerance (Mass, 1986).

\section{Potassium ion content}

$\mathrm{K}^{+}$has an important role in enzyme activation in plant cells (Tester and Davenport, 2003). Fig. 7 shows the effect of $\mathrm{NaCl}$ on the potassium concentration in the embryogenic callus and somatic embryos of date palm Hayani cv. It is clear that different concentrations of $\mathrm{NaCl}$ significantly decreased the level of $\mathrm{K}^{+}$.

The highest concentration of $\mathrm{K}^{+}(4.35 \mathrm{mg} / \mathrm{g} \mathrm{dw})$ recorded in the control treatment; however, with added $\mathrm{NaCl}$ at different concentration $(500,1000$, 1500 and $2000 \mathrm{ppm}$ ) the level of $\mathrm{K}^{+}$decreased gradually $(4.22,4.18,4.10$ and $4.02 \mathrm{mg} / \mathrm{g} \mathrm{dw}$, respectively) in embryogenic callus. On the other hand, in the somatic embryos, as shown in Fig. 7 the increase of $\mathrm{NaCl}$ concentration at 1500 and $2000 \mathrm{ppm}$ led to a significant decrease in $\mathrm{K}^{+}$ concentration ranged from $(4.52 \mathrm{mg} / \mathrm{g} \mathrm{dw})$ under the control treatment to (4.31 and 4.28 $\mathrm{mg} / \mathrm{g} \mathrm{dw}$, respectively) under the highest level of salinity.

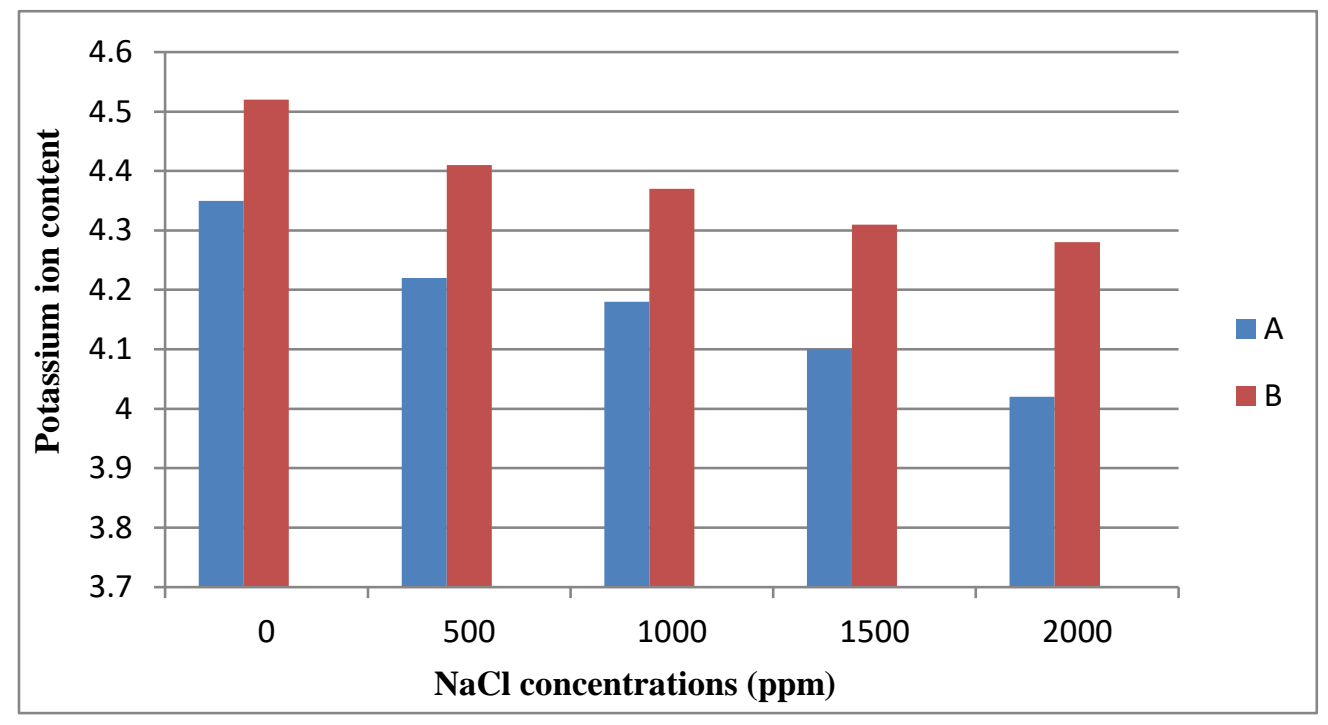

Fig. 7. Effect of different concentrations of $\mathrm{NaCl}$ on potassium ion content $(\mathrm{mg} / \mathrm{g} \mathrm{dw})$ in embryogenesis callus (A) and somatic embryos (B) after 8 weeks in culture

This reduction in levels of $\mathrm{K}^{+}$is due to excessive accumulation of $\mathrm{Na}^{+}$and $\mathrm{Cl}^{-}$, which reduces the accumulation of $\mathrm{K}^{+}$. Furthermore, osmotic stress induced by salinity also reduces water uptake and hence accumulation of potassium (Abbas et al., 2012). There is a significant reduction of the concentration of $\mathrm{K}^{+}$in the callus tissues of Citrus sinensis (L.) and increasing the concentration of $\mathrm{NaCl}$ in the culture medium. This decrease in $\mathrm{K}^{+}$ concentration is due to the presence of $\mathrm{Na}^{+}$at high concentration, which competes with $\mathrm{K}^{+}$uptake and may also block the $\mathrm{K}^{+}$specific transporters of the callus cells under salinity (Zhu, 2003) resulting in toxic levels of $\mathrm{Na}^{+}$as well as insufficient concentration of $\mathrm{K}^{+}$for enzymatic reactions and osmotic adjustment.

The reduction in $\mathrm{K}^{+}$concentration in callus cells under salt stress could be explained by the change in expression and function of transporter as well as the ion channels especially those related to $\mathrm{K}^{+}$(Arzani and Ashraf, 2016). The increase nutritional uptake of both $\mathrm{Na}^{+}$and $\mathrm{K}^{+}$might have led to the retention of water in the callus (Chaudhary et al., 1997). 
Increasing the concentration of $\mathrm{NaCl}$ in the culture medium generally resulted in increase the $\mathrm{Na}^{+}$and reduction in $\mathrm{K}^{+}$concentrations. However, at $25 \mu \mathrm{M}$ $\mathrm{NaCl}$, the only level at which callus growth was significantly enhanced; an increase in $\mathrm{K}^{+}$content was noted, in comparison to the $\mathrm{NaCl}$ free control (Al-Khayri, 2002).

$\mathrm{Na}^{+}$accumulation in tissues under salinity stress is generally considered as a major factor behind the adverse effect of salinity on nutrient uptake and growth (Shibli et al., 2001). The increase in $\mathrm{Na}^{+}$ content of cells was accompanied by a decrease in $\mathrm{K}^{+}$accumulation and differences in $\mathrm{Na} / \mathrm{K}$ ratio under saline conditions (Cherian and Reddy, 2003).
The somatic embryos cultures after treatment with different level of salinity stress for two months were transferred to optimized regeneration medium without $\mathrm{NaCl}$. The recovery percentage decreased with increase in $\mathrm{NaCl}$ concentration. It was observed that regeneration of embryo cultures without salt or with low concentrations of $\mathrm{NaCl}$ was better than treated with high concentrations of $\mathrm{NaCl}$ (1500 and $2000 \mathrm{ppm})$. The shoots produced from the experiment of salinity with using low concentration of $\mathrm{NaCl}$ were the strongest in growth and ability to continue to rooting stage, as shown in Fig. 8.
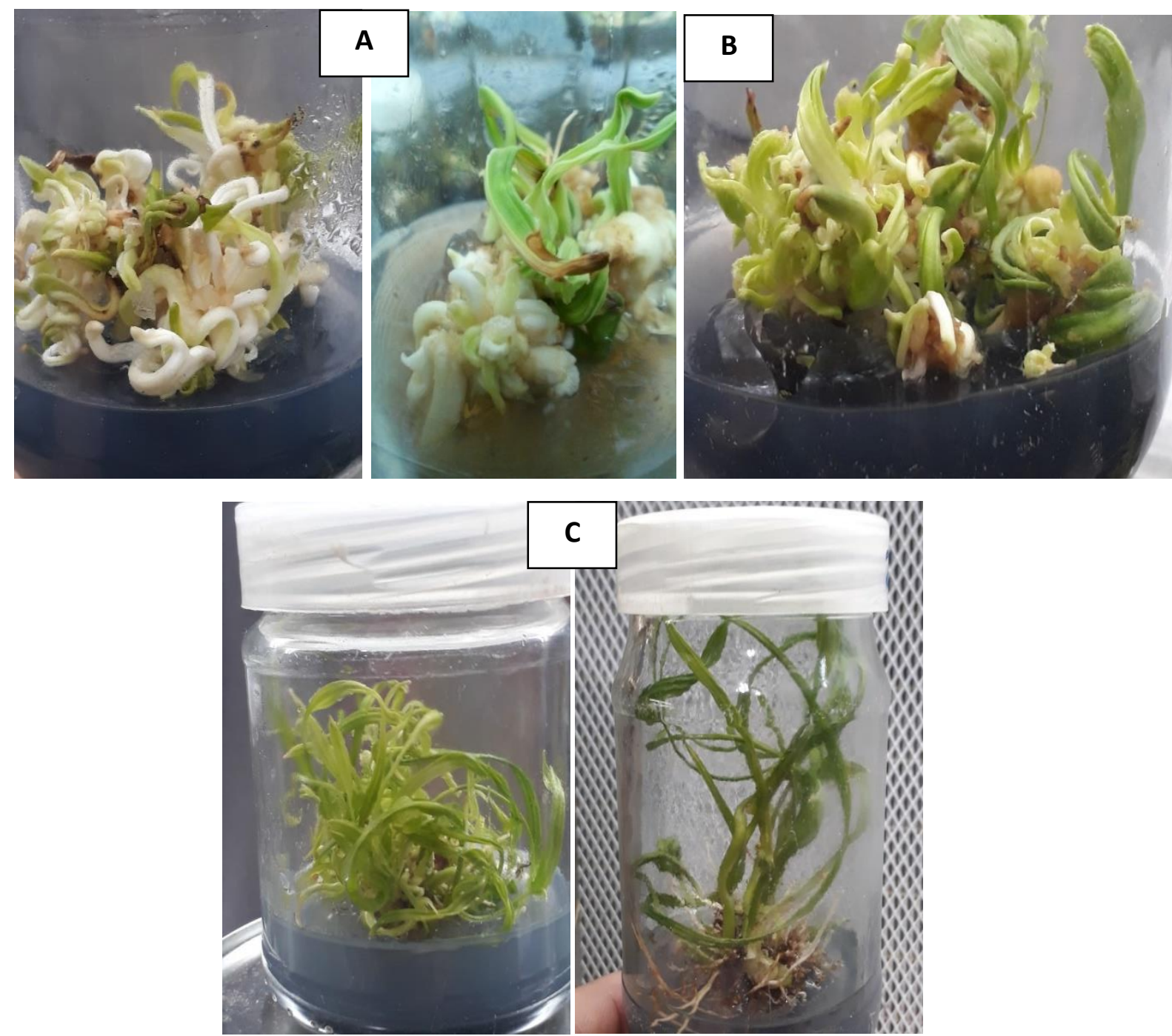

Fig. 8. Different stages of somatic embryos to produce the shoots. A: Embryos culture, B: Shoots proliferation from embryos, $\mathrm{C}$ : Shoot elongation and rooting stage 


\section{REFERENCES}

Abadı 'a, A.; Belkhodja, R.; Morales, F. and Abadı 'a, J. (1999). Effects of salinity on the photosynthetic pigment composition of barley (Hordeum vulgare L.) grown under a triple-linesource sprinkler system in the field. J. Plant Physiol., 154: 392-400.

Abahmane, L. (2013). Recent achievements in date palm (Phoenix dactylifera L.) micropropagation from inflorescence tissues. Emir. J. Food Agric., 25: 863-874.

Abass, M. H. (2013). Microbial contaminants of date palm (Phoenix dactylifera L.) in Iraqi tissue culture laboratories. Emirates. J. Food Agric., 25 (11): 875-882.

Abbas, M. F.; Jasim, A. M. and Al-Taha, H. A. (2013). Effect of exogenons proline on callus growth of Citrus sinensis (L.) Osbeck, under salt stress. International Journal of Natural Sciences Research, pp: $1-10$.

Abbas, M. F.; Jasim, A. M. and Al-Zubaidy, B. H. (2012). The Effect of Proline on Growth and Ionic Composition of Embryogenic Callus and Somatic Embryos of the date Palm (Phoenix dactylifera L. cv. Ashkar) Under $\mathrm{NaCl}$ Stress. International Journal of Farming and Allied Sciences, 1 (3): 82-87.

Agastian, P.; Kingsley, S. J. and Vivekanandan, M. (2000). Effect of salinity on photosynthesis and biochemical characteristics in mulberry genotypes. Photosynthesis, 38: 287-290.

Ahmad, P. (2014). Oxidative damage to plants. Academic Press, New York

Alamgir, A. N. M. and Ali, M. Y. (1999). Effect of salinity on leaf pigments, sugar and protein concentrations and chloroplast ATPase activity of rice (Oryza sativa L.). Bangladesh Journal of Botany, 28: 145-149.

Al-Bahrany, A. M. and Al-Khayri, J. M. (2012). In vitro responses of date palm cell suspensions under osmotic stress induced by sodium, potassium and calcium salts at different exposure durations. Am. J. Plant Physiol., 7: 120-134.

Al-Dhebiani, A. Y.; Metwali, E. M. R.; Soliman, H. I. A. and Howladar, S. M. (2018). Response of Different Date Palm Cultivars to Salinity and Osmotic Stresses using Tissue Culture Technique. International Journal of Agriculture and Biology, 7 (20): 1581-159.

Al-Kabi, H. K., (2004). Effect of sodium chloride and proline on the growth of the date palm (Phoenix dactylifera L.) in vitro. Ph.D. Thesis, Basrah University, Iraq, pp. 165.

Al-Khalifah, N. S. and Askari, E. (2011). Growth abnormalities associated with micropropagation of date palm. In: Date Palm Biotechnology, pp: 205 219.
Al-Khayri, J. M and Ibraheem, Y. (2014). In vitro selection of abiotic stress tolerant date palm (Phoenix dactylifera L.): a review. Emir. J. Food Agri., 26 (11): 921-933.

Al-Khayri, J. M. (2013). Factors affecting somatic embryogenesis in date palm (Phoenix dactylifera L.) In: Aslam, J.; Srivastava, P. S. and Sharma, M. P. (eds) Somatic embryogenesis and genetic transformation in plants. Narosa Publishing House, New Delhi, pp 15-38.

Al-Khayri, J. M. and Al-Bahrany, A. M. (2004). Growth, water content, and proline accumulation in drought-stressed callus of date palm. Biol. Plant 48: 105-108.

Al-Khayri, J. M. (2002): Growth, proline accumulation and ion content in sodium chloridestressed callus of date palm. In Vitro Cellular and Developmental Biology - Plant, 38: 79-82.

Al-Khayri, J. M.; Jain, S. M. and Johnson, D. V. (2015). Date Palm Genetic Resources and Utilization, Africa and the Americas, Vol. 1. Springer, Dordrecht.

Al-Mansoori, T. A.; Alaa El-Deen, M. N. and Peter, D. S. C. (2007). Evaluation of In Vitro Screening Techniques for Salt Tolerance in Date Palm. Acta Horticulturae, 736 (28): 301 - 307.

AL-Mayahi, A. M. W. (2015). An efficient protocol for indirect somatic embryogenesis and shoot organogenesis from leaf segments of date palm (Phoenix dactylifera L.) cv. Quntar. African Journal of Agricultural Research, 10 (10): 1031-1042.

Al-Shahib, W. and Marshall, R. J. (2003). The fruit of the date palm: it's possible use as the best food for the future. Int. J. Food Sci. Nutr., 54: 247259.

Alvarez, I.; Tomaro, M. L. and Benavides, M. P. (2003). Changes in polyamines, proline and ethylene in sunflower calluses treated with $\mathrm{NaCl}$. Plant Cell Tissue and Organ Culture, 74 (1): 51-59.

Al-Zubaydi, S.; Jassim, A. and Zair, H. (2012). Effect of sodium chloride and proline on embryo formation and germination through in vitro micropropagation of date palm (Phoenix dactylifera L.) cv. Barhee. J. Agr. Sci. Tech. 3: 313-320.

Amini, F.; Ghanbarzadeh, Z. and Askary, M. (2017). Biochemical and Physiological Response of Salsola arbuscula Callus to Salt Stress. Iranian Journal of Science and Technology, Transactions A: Science, 41: 321-328.

Arslan, D.; Zencirci, N.; Etoz, M.; Ordu, B. and Bataw, S. (2016). Bread wheat responds salt stress better than einkorn wheat does during germination. Turkish Journal of Agriculture and Forestry, 40: 783-794.

Arzani, A. (2008). Improving salinity tolerance in crop plants. A biotechnological view. In Vitro Cell. Dev. Biol. Plant, 44: 373-383. 
Arzani, A. and Ashraf, M. (2016). Smart engineering of genetic resources for enhanced salinity tolerance in crop plants. Crit. Rev. Plant Sci., 35: 146-189.

Ashraf, M. (1994). Organic substances responsible for salt tolerance in Eruca sativa. Biol. Plant., 36: 255-259.

Ashraf, M. and Foolad, M. R. (2007). Roles of glycine betaine and proline in improving plant abiotic stress resistance. Environ. Exp. Bot., 9: 206216.

Ashraf, M. and Harris, P. J. C. (2004). Potential biochemical indicators of salinity tolerance in plants. Plant Sci., 166: 3-16.

Bartlets, D. and Sunkar, R. (2005). Drought and salt tolerance in plants. Critic. Rev. Plant Sci., 24: 23-58.

Bates, L. S.; Waldren, R. P. and Teake, I. D. (1973). Rapid determination of free proline for water stress studies. Plant and Soil, 39: 205-207.

Bekheet, S. H.; Taha, S. H.; Sawires, E. S. and Elbahr, M. K. (2000). Salt stress in tissue culture of Asparagus officinalis. Egyptian Journal of Horticulture, 27: 275-287.

Bradford, M. M. (1976). A rapid and sensitive method for the quantitation of microgram quantities of protein utilizing the principle of protein-dye binding. Analytical Biochemistry, 72 (1-2): 248254.

Chaudhary, M. T.; Merrett, M. J. and wainwright, S. J., (1997). Growth, ion content and proline accumulation in $\mathrm{NaCl}$ selected and nonselected cell lines of lucerne cultured on sodium and potassium salts. Plant Sci., 127: 71-79.

Cherian, S. and Reddy, M. P. (2003). Evaluation of $\mathrm{NaCl}$ tolerance in callus cultures of Suaeda nudiflora Moq. Biol. Plant., 46: 193-198.

Dhanapackiam, S. and Ilyas, M. H. M. (2010). Effect of salinity on chlorophyll and carbohydrate contents of Sesbania grandiflora seedlings. Indian J. Sci. Technol., 3: 64-66.

Duncan, D. B. (1955). Multiple range and multiple F test. Journal of Biometrics, 11: 1 - 42.

Eke, C. R.; Peter, A. and Omorefe, A. (2005). Somatic embryogenesis in date palm (Phoenix dactylifera L.) from apical meristem tissues from 'zebia' and 'loko' landraces. Afr. J. Biotechnol., 4: 244-246.

El-Far, A. H.; Shaheen, H. M.; Abdel-Daim, M. M.; Al Jaouni, S. K. and Mousa, S. A. (2016). Date palm (Phoenix dactylifera): protection and remedy food. Curr. Trends Nutraceuticle, 1 (29): 1 10.

El-Hadrami, A.; Daayf, F. and El-Hadrami, I. (2011). In vitro selection for abiotic stress in date palm. Date palm biotechnology, Springer, Dordrecht. In: (Eds.) pp: 237-252.
El-Hammady, A. E.; Wanas, W. H.; El-Saidi, M. T. and Shahin, M. F. (1999). Impact of proline application on growth of grape plantlets under salt stress in vitro. Arab Univ. J. Agric. Sci., 7: 191-202.

El-Sharabasy, S. F.; Wanas, W. H. and AlKerdany, A. Y. (2008). Effect of salinity stress on some date palm cultivars during proliferation stage in vitro. Arab J. Biotech., 11: 273-280.

Fidalgo, F.; Santos, A.; Santos, I. and Salema, R. (2004). Effects of long-term salt stress on antioxidant defense system, leaf water relations and chloroplast ultra-structure of potato plant. Annals of Applied Biology, 145: 185-192.

Flowers, T. J. and Colmer, T. D. (2008). Salinity tolerance in halophytes. New Phytol., 179: 945-963.

Gandonou, C. B.; Errabii, T.; Abrini, J.; Idaomar M. and Senhaji, N. S. (2006). Selection of callus cultures of sugarcane (Saccharum sp.) tolerant to $\mathrm{NaCl}$ and their response to salt stress. Plant Cell Tissue and Organ culture, 87 (1): 9-16.

Golkar, P. and Taghizadeh, M. (2018). In vitro evaluation of phenolic and osmolite compounds, ionic content, and antioxidant activity in safflower (Carthamus tinctorius L.) under salinity stress. Plant Cell Tissue and Organ Culture, 134: 357-368.

Golkar, P.; Amooshahi, F. and Arzan, A. (2017). The effects of salt stress on physio-biochemical traits, total phenolic and mucilage content of Plantago ovata Forsk under in vitro conditions. Journal of Applied Botany and Food Quality, 90: $224-231$.

Golkar, P.; Taghizadeh, M. and Yousefian, Z. (2019). The effects of chitosan and salicylic acid on elicitation of secondary metabolites and antioxidant activity of safflower under in vitro salinity stress. Plant Cell Tissue and Organ Culture, 137 (3): 575585 .

Gomez, K. A. and Gomez, A. A. (1984). Statistical Procedures for Agricultural Research. John Wiley and Sons, New York, USA, 680 p.

Huang, W. L. and Liu, L. F. (2002). Carbohydrates metabolism in rice during callus induction and shoot regeneration induced by osmotic stress. Bot. Bull. Acad. Sci., 43: 107-111.

Ibraheem, Y. (2013). In vitro regeneration systems for economically important date palm (Phoenix dactylifera L.) cultivars. PhD Dissertation. Verlag Dr. Kö ster, HUMBOLDT UNIVERSITY OF BERLIN. ISBN13: 9783895748318.

Ibraheem, Y. M.; Pinker, I. and Bo“hme, M. (2012). The effect of sodium chloride-stress on 'Zaghloul' date palm somatic embryogenesis. Acta Hortic., 961: 367-373.

Ibrahim, K.; Alromaihi, K. B. and Elmeer, K. M. S. (2009). Influence of different media on in vitro roots and leaves of date palm somatic embryos cvs. 
Kapakap and Tharlaj. Am. Eurasian J. Agric. Environ. Sci., 6: 100-103.

Jain, S. M. (2007). Recent advances in date palm tissue culture and mutagenesis. Acta Hortic., 736: 205-211.

Jasim, A. M.; Abbas, M. F. and Alzubaidy, B. H. (2010). Effect of Salt Stress and Proline on Chemical Content of Embryogenic Callus and Somatic Embryos of Date Palm (Phoenix dactylifera L.) cv. Ashkar. Acta Horticulturae, 882 (882): 219 224.

Jasim, A. M.; Abbas, M. F. and Shareef, H. J. (2016). Calcium application mitigates salt stress in date palm (Phoenix dactylifera $\mathrm{L}$.) offshoots cultivars of Berhi and Sayer. Acta Agric. Slovenica, 107: 103-112.

Kaouthar, S.; Jean, D. and Chedly, D. (2001). Genotype variability for tolerance to salinity of N2fixing bean. Agronomie, 21: 675-682.

Khedr, H. A.; Abbas, M. A.; Abdel-Wahid, A. A.; Quick, W. P. and Abo-Gadallah, G. M. (2003). Proline induces the expression of salt-stress responsive proteins and improve the adaptation of Pancratium maritimum L. to salt-stress. Journal of Experimental Botany, 54: 2253-2262.

Lokhande, V. H.; Nikam, T. D. and Penna, S. (2010). Biochemical, physiological and growth changes in response to salinity in callus cultures of Sesuvium portulacastrum L. Plant Cell Tissue and Organ Culture, 102: 17-25.

Lokhande, V. H.; Nikam, T. D.; Patade, V. Y.; Ahire, M. L. and Suprasanna, P. (2011). Effects of optimal and supra-optimal salinity stress on antioxidative defence, osmolytes and in vitro growth responses in Sesuvium portulacastrum L. Plant Cell Tissue and Organ Culture, 104: 41-49.

Lutts, S.; Almansouri, M. and Kinet, J. M. (2004). Salinity and water stress have contrasting effects on the relationship between growth and cell viability during and after stress exposure in durum wheat callus. Plant Sci., 167 (1): 9-18.

Lutts, S.; Kinet, J. M. and Bouharmont, J. (1999). Improvement of rice callus regeneration in the presence of $\mathrm{NaCl}$. Plant Cell Tissue and Organ Culture, 57: 3-11.

Maas, E. V. (1986). Salt tolerance of plants. Appl. Agric. Res., 1: 12-26.

McCubbin, M. J.; Staden, J. Van and Zaid, A. (2000). A Southern African survey conducted for off-types on date palm production using somatic embryogenesis. In: Proceedings of date palm international symposium, Windhoek, pp: 68-72.

Mehr, Z. S. (2013). Salt-induced changes in germination and vegetative stages of Anethum graveolens L. Journal of Stress Physiology and Biochemistry, 9 (2): 189-198.
Mousavi, A.; Lessani, H.; Babalar, M.; Talaei, A. R. and Fallahi, E. (2008). Influence of salinity on chlorophyll, leaf water potential, total soluble sugars and mineral nutrients in two young olive cultivars. J. Plant Nutr., 31: 1906-1916.

MSTAT Development Team (1989). MSTAT user's guide: a microcomputer program for the design management and analysis of agronomic research experiments. Michigan State University, East Lansing, USA.

Munns, R. (2002). Comparative physiology of salt and water stress, Plant Cell Environ., 25: 239-250.

Munns, R. (2005). Genes and salt tolerance: bringing them together. New Phytol., 167: 645-663.

Munns, R. and Tester, M. (2008). Mechanisms of salinity tolerance. Annu. Rev. Plant Biol. 59: 651681.

Murashige, T. and Skoog, F. (1962). A revised medium for rapid growth and bioassays with tobacco tissue cultures. Physiolo. Plant, 13: 473 - 497.

Muthukumarasamy, M.; Dutta-Gupta, S. and Panneerselvam, R. (2000). Enhancement of peroxidase, polyphenol oxidase and superoxide dismutase activities by Triadimefon in $\mathrm{NaCl}$ stressed Raphanus sativus L. Biologia Plantarum, 43: 317320.

Nawaz, M. F.; Gul, S.; Tanvir, M. A.; Akhtar, J.; Chaudhary, S. and Ahmad, I. (2016). Influence of $\mathrm{NaCl}$-salinity on $\mathrm{Pb}$-uptake behavior and growth of River Red gum tree (Eucalyptus camaldulensis Dehnh.). Turkish Journal of Agriculture and Forestry, 40: 425-432.

Palma, F.; Lluch, C.; Iribarne, C.; GarridoGarcia, J. M. and Tejera-Garcia, N. A. (2009). Combined effect of salicylic acid and salinity on some antioxidant activities, oxidative stress and metabolic accumulation in Phaseolus vulgaris. Plant Growth Regulation, 58: 307-316.

Parida, A.; Das, A. B. and Das, P. (2002). $\mathrm{NaCl}$ stress causes changes in photosynthetic pigments, proteins and other metabolic components in the leaves of a true mangrove, Bruguiera parviflora, in hydroponic cultures. Journal of Plant Biology, 45: 28-36.

Patade, V. Y.; Bhargava, S. and Suprasanna, P. (2011). Salt and drought tolerance of sugarcane under iso-osmotic salt and water stress: growth, osmolytes accumulation and antioxidant defense. J. Plant Interact., 6 (4): 275-282.

Queiros, F.; Fidalgo, F.; Santos, I. and Salema, R. (2007). In vitro selection of salt tolerant cell lines in Solanum tuberosum L. Biologia Plantarum, 51 (4): $728-734$.

Quiroz-Figueroa, F. R.; Rojas-Herrera, R.; Galaz-Avalos, R. M. and Loyola-Vargas, V. M. (2006). Embryo production through somatic embryogenesis can be used to study cell 
differentiation in plants. Plant Cell Tissue and Organ Culture, 86: 285-301.

Rafiq, M.; Mali, M.; Khatri, A. and Dahot, M. U. (2008). Callus induction and regeneration in local mungbean (Vigna radiate L. Wilczek) under salt stress. J. Biotechnol, 136: 147-169.

Rahnama, H. and Ebrahimzadeh, H. (2004). The effect of $\mathrm{NaCl}$ on proline accumulation in potato seedlings and calli. Acta Physiologiae Plantarum, 26: 263-270.

Rains, D. W.; Croughan, S. S. and Croughan, T. P. (1986). Isolation and characterization of mutant cell lines and plants: Salt tolerance. Pages 537-547 in Vasil I.K. (ed) Cell culture and somatic cell genetics of plants Vol. 3. Plant regeneration and genetic variability. Academic Press, New York.

Rus, A. M.; Rios, S.; Olmos, E.; Santa-Cruz, A. and Bolarin, M. C. (2000). Long-term culture modifies the salt responses of callus lines of salttolerant and salt-sensitive tomato species. J. Plant Physiol., 157: 413-420.

Sabbah, S. and Tal, M. (1990). Development of callus and suspension cultures of potato resistant to $\mathrm{NaCl}$ and mannitol and their response to stress. Plant Cell Tissue and Organ Culture, 21: 119-128.

Saed-Moucheshi, A.; Shekoofa, A. and Pessarakli, M. (2014). Reactive oxygen species (ROS) generation and detoxifying in plants. J. Plant Nutr., 37: 1573-1585.

Sairam, R. K. and Tyagi, A. (2004). Physiology and molecular biology of salinity stress tolerance in plants. Current Science, 86: 407 - 421.

Santos, V. A.; Arrigoni-Blank, F. M.; Blank, F. A.; Diniz, C. E. L. and Fernandes, P. M. R. (2011). Biochemical profile of callus cultures of Pogostemon cablin (Blanco) Benth. Plant Cell Tissue and Organ Culture, 107: 35-43.

Shankhdhar, D.; Shankhdhar, S. C.; Mani, S. C. and Pant, R. C. (2000): In vitro selection for salttolerance in rice. Biologia Plantarum, 43 (3): 477 480.

Sharry, E. S. and Teixeira da Silva, J. A. (2006). Effective Organogenesis, Somatic Embryogenesis and Salt Tolerance Induction In Vitro in the Persian Lilac Tree (Melia azedarach L.). Floriculture, Ornamental and Plant Biotechnology, Volume II: 317-324.

Shibli, R. A.; Sawwan, J.; Swaidatm I. and Tahat, M. (2001). Increased phosphorus mitigates the adverse effects of salinity in tissue culture. Comm. Soil Sci. Plant Anal., 32: 429-440.

Shonjani, S. (2002). Salt sensitivity of rice, maize, sugar beet and cotton during germination and early vegetative growth. Ph.D thesis. Institute of Plant Nutrition, Justus Liebig University, Giessen.

Skoog, D. A.; West, D. M.; Holler, F. J. and Crouch, S. R. (2007). Analytical Chemistry: An
Introduction, New Age International PVT, UK 594631.

Sofy, M. R and Fouda, H. M. (2013). Spermidine as modulator of growth, some metabolic activities and reproductive development of Helianthus tuberosus plants grown in two types of soil. Nature and Science, 11 (12): 161- 171.

Sotiropoulos, T. E.; Fotopoulos, S.; Dimassi, K. N. and Tsirakoglou, V. (2006). Response of the pear rootstock to boron and salinity in vitro. Biol. Plant, 50: 779-781.

Szabados, L. and Savoure, A. (2010). Proline: a multifunctional amino acid. Trends in Plant Science, 15 (2): 89-97.

Taha, R. A. and Hassan, M. M. (2014). Effect of low levels of salinity on development of date palm embryogenic cultures. Asian J. Agric. Sci., 6: 69-74.

Tan, J.; Zhao, H.; Hong, J.; Han, Y.; Li, H. and Zhao, W. (2008). Effects of exogenous nitric oxide on photosynthesis, antioxidant capacity and proline accumulation in wheat seedlings subjected to osmotic stress. World J. Agric. Sci., 4: 307-313.

Tester, M. and Davenport, R. J. (2003). $\mathrm{Na}^{+}$ transport and $\mathrm{Na}^{+}$tolerance in higher plants. Annals of Botany, 91 (5): 503-527.

Wang, H. L.; Lee, L. P. and Su, J. C. (1999). Effect of sorbitol induced osmotic stress on the change of carbohydrates and free amino acid pools in potato cell suspension culture. Bot. Bull. Acad. Sci., 40: 219-225.

Watanabe, S.; Kojima, K.; Ide, Y. and Sasaki, S. (2000). Effects of saline and osmotic stress on proline and sugar accumulation in Populus euphratica in vitro. Plant Cell Tissue and Organ Culture, 63: 199-206.

Whiting, D. and Wilson, C (2003). Colorado master gardener. Academic Press, Colorado.

Yaish, M. M. (2015). Proline accumulation is a general response to abiotic stress in the date palm tree (Phoenix dactylifera L.). Genetics and Molecular Research, 14 (3): 9943-9950.

Yu, J.; Chen, S.; Zhao, Q.; Wang, T.; Yang, C. and Diaz, C. (2011). Physiological and proteomic analysis of salinity tolerance in Puccinellia tenuiflora. J. Proteome Res., 10 (9): 3852-70.

Zhang, F.; Yang, Y. L.; He, W. L.; Zhao, X. and Zhang, L. X. (2004). Effects of salinity on growth and compatible solutes of callus induced from Populus euphratica. In vitro Cell Dev. Biol. Plant, 40: 491-494.

Zhu, J. K. (2003). "Regulation of ion homeostasis under salt stress," Curr. Opin. Plant Biol., 6: 441 445 . 